\title{
Uptake of lead by futed pumpkin (Telfairia occidentalis Hook F.) in an ultisol
}

\author{
Ehi R obert Orhue* and Uzu Frank \\ Department of Soil Science, Faculty of Agriculture, University of Benin P.M.B. 1154 Benin city, Edo state, NIGERIA \\ *Corresponding author. E-mail: orhuerob@yahoo.com
}

\begin{abstract}
Pot and field trials were conducted at the Faculty of Agriculture, University of Benin to determine the influence of $\mathrm{Pb}$ on some agronomic characters of Telfairia occidentalis and some chemical properties of soil. Completely randomized and randomized completely block designs were used in greenhouse and field trials respectively. In the greenhouse trial, lead nitrate $\left(\mathrm{Pb}\left(\mathrm{NO}_{3}\right)_{2}\right)$ was applied at rates of $0,50,100$ and $200 \mathrm{mg}$ per $5 \mathrm{~kg}$ sieved and air-dried soil obtained from a depth of $0-15 \mathrm{~cm}$. The pot rates equivalent to $0,20,40$ and $80 \mathrm{kgha}^{-1}$ were used in the field trial. Results indicated that the soil used was texturally sandy loam and an ultisol as demonstrated by its low base saturation. The $\mathrm{pH}$, organic carbon, Effective Cation Exchange Capacity (ECEC), Exchangeable acidity, N, K, Mg, Ca, Na, Fe, Mn, Zn, free Fe and Al oxides, Amorphous Fe and Al oxides content of the soil decreased inconsistently. The organic carbon however increased in the field while the available $\mathrm{P}$ appreciated in the entire trials. The $\mathrm{Pb}$ content of the soil increased with the levels of $\mathrm{Pb}$ treatments when compared with the control throughout the trials. The $\mathrm{N}, \mathrm{P}, \mathrm{K}, \mathrm{Mg}, \mathrm{Ca}, \mathrm{Na}, \mathrm{Fe}, \mathrm{Mn}$ and $\mathrm{Zn}$ content of shoot and root as well as their uptake also decreased consistently with increasing $\mathrm{Pb}$ treatments. In addition, the $\mathrm{Pb}$ content as well as uptake by the shoot and root also increased consistently with increased rates of the $\mathrm{Pb}$ applied in the trials with the minimum levels of the $\mathrm{Pb}$ content and uptake recorded at the control treatments. The crude protein content decreased with increased heavy metal treatments in both root and shoot with the control having the highest crude protein content. The highest crude protein percentage was recorded in the shoot compared to the root. A decrease in the dry matter yield with increased $\mathrm{Pb}$ treatments in shoot and root was recorded in the trials. Results also showed that the $\mathrm{Pb}$ influenced the height, collar girth, leaf area and number of leaves with control treatments higher than other treatments at final harvest. The manifestation of anthocyanin pigmentation in $200 \mathrm{mg} \mathrm{Pb}^{2}$ and $80 \mathrm{~kg} \mathrm{~Pb} \mathrm{ha}^{-1}$ treatments revealed the negative influence of the $\mathrm{Pb}$ on the phosphorus uptake by Telfaria occidentalis.
\end{abstract}

Keywords: Heavy metal, Uptake, Ultisol, Metal excluder, Pumpkin

\section{INTRODUCTION}

Lead $(\mathrm{Pb})$ is one of those heavy metals that are potentially toxic to plants and animals at low concentration. This metal in addition to its natural existence has been elevated in the environment by anthropogenic activities such as metal rich mine tailings, metal smelting, electroplating, battery recycling, wood treating, fuel burning and fuel production, downwash from power lines, intensive agriculture and sludge dumping (Moffat, 1995; Forstner, 1995). The major recipient of this metal is the soil. The lead is not very mobile in the soil and very little of it leach through the soil profiles. Khan and Frankland (1983) observed that $\mathrm{Pb}$ is removed from the soil by plants than was leached through the soil profile.

The phytotoxicity of $\mathrm{Pb}$ depends on the concentration, type of salts and plant species involved (Azmat and Haider, 2007). Godbold and Kettner (1991) reported that though effects of $\mathrm{Pb}$ are more prominent at higher concentration and duration, in some cases, lower concentration might influence various metabolic processes in plants. Haider et al. (2006) reported that $\mathrm{Pb}$ affects seed germination, growth of seedlings and photosynthesis of Phaseolus vulgaris. It has also been observed that at higher concentration of $600 \mathrm{ppm} \mathrm{Pb}$ the biomass production and chlorophyll concentration decreased to level below the control in Phaseolus vulgaris, alf-alfa (M edicago sativa), avena (Avena sativa) and rye grass (Lolium multiflorun) plants ( Pinero et al. , 2002 ). Keresan et al. (2001) found reduced protein and nitrogen components of young pea plant and that the accumulation of $\mathrm{Pb}$ in plants increased with increase in the level of $\mathrm{Pb}$ application. Eun et al. (2002) recorded a decrease in $\mathrm{Ca}, \mathrm{Fe}$ and $\mathrm{Zn}$ content of root tips of maize and significant reduction in $\mathrm{Ca}, \mathrm{Fe}, \mathrm{Mn}$ and $\mathrm{Zn}$ uptake by Phaseolus vulgaris (Geeblen et al., 2002) due to increase in the application of $\mathrm{Pb}$. The cultivation of crops in $\mathrm{Pb}$ polluted soils and subsequent consumption is one of the ways of introducing $\mathrm{Pb}$ into the food chain. Regular consumption of crops laden with heavy metals leads to bioaccumulation in the body in an unchanged state and are continuously accumulated during the life of an organism causing bio-magnification (Clark, 1995). 
Table 1. Physico-chemical properties of the soil used in the trials.

\begin{tabular}{|c|c|c|}
\hline Properties & $\begin{array}{c}\text { Greenhouse } \\
\text { value }\end{array}$ & $\begin{array}{l}\text { Field } \\
\text { value }\end{array}$ \\
\hline $\mathrm{pH}(1: 1)$ ( soil:water) & 4.71 & 5.64 \\
\hline Organic carbon $\left(\mathrm{gkg}^{-1}\right)$ & $11 . .1$ & 10.0 \\
\hline Total N $\left(\mathrm{gkg}^{-1}\right)$ & $1 . .3$ & 1.6 \\
\hline $\operatorname{Av} P\left(\mathrm{mgkg}^{-1}\right)$ & 3.19 & 5.76 \\
\hline $\mathrm{Ca} \mathrm{cmol} \mathrm{kg}{ }^{-1}$ & 0.96 & 0.97 \\
\hline $\mathrm{Mg} \mathrm{cmol} \mathrm{kg}{ }^{-1}$ & 0.64 & 0.66 \\
\hline $\mathrm{K} \mathrm{cmol} \mathrm{kg}^{-1}$ & 0.11 & 0.13 \\
\hline $\mathrm{Na} \mathrm{cmol} \mathrm{kg}^{-1}$ & 0.12 & 0.20 \\
\hline Exch Acidity cmol kg-1 & 3.58 & 2.68 \\
\hline ECEC cmolkg ${ }^{-1}$ & 5.41 & 3.93 \\
\hline Base saturation (\%) & 33.83 & 31.81 \\
\hline Free $\mathrm{Fe}$ Oxides $\%$ & 6.38 & 6.40 \\
\hline Free $\mathrm{Al}$ Oxides $\%$ & 1.73 & 1.21 \\
\hline Amorphous Fe oxide $\%$ & 0.07 & 0.08 \\
\hline Amorphous $\mathrm{Al}$ oxide $\%$ & 0.03 & 0.03 \\
\hline $\mathrm{Pb} \mathrm{mgkg}{ }^{-1}$ & 0.3 & 0.04 \\
\hline Fe mgkg ${ }^{-1}$ & 0.03 & 0.04 \\
\hline $\mathrm{Mn} \mathrm{mgkg}^{-1}$ & 0.05 & 0.05 \\
\hline $\mathrm{Zn} \mathrm{mgkg}^{-1}$ & 0.65 & 0.67 \\
\hline Sand gkg $^{1}$ & 865.31 & 864.32 \\
\hline Silt $\mathrm{gkg}^{1}$ & 12.39 & 14.37 \\
\hline Clay $\operatorname{gkg}^{1}$ & 122.30 & 121.31 \\
\hline Textural class & Sandy loam & Sandy loam \\
\hline
\end{tabular}

The test crop is widely cultivated in any available space that can accommodate its growth without taken into cognisant the quality of the soil. The fluted pumpkin leaves and seeds are highly nutritive and widely consumed in tropical Africa. The level of heavy metal in this plant is not determined prior to consumption Therefore the aim of this work was to determine the influence of $\mathrm{Pb}$ on some agronomic characters of the plant, nutrient content and their uptake and some chemical properties of the soil.

\section{MATERIALS AND METHODS}

Site of the trial: The greenhouse and field trials were conducted at the Faculty of Agriculture, University of Benin, Benin City., Nigeria.

Greenhouse trial: In the greenhouse study, soil sample was collected from surface $0-15 \mathrm{~cm}$ depth of soil. The soil collected was bulked, mixed thoroughly, air dried and sieved to remove debris. Thereafter, $5 \mathrm{~kg}$ of the composite soil was weighed and put in each of the plastic pots. In this trial the total number of plastic pots used was 48 . Each plastic pot labeled for the various treatments. Each replicate had 16 plastic pots with 4 pots per treatment. The lead nitrate $\left(\mathrm{Pb}\left(\mathrm{NO}_{3}\right)_{2}\right)$ used was applied at $0,50,100$, $200 \mathrm{mg}$ per $5 \mathrm{~kg}$ soil. The applied heavy metal was thoroughly mixed with the soil and then left for 7 days to enable the heavy metal equilibrate with the soil. The experiment was laid out in a completely randomized design with three replicates. Before transplanting the seedlings, the soil was moistened to field capacity with distilled water. The plants were watered with distilled water throughout the period of the crop growth. Excess moisture drainage from perforation at the base of each pot was collected by a saucer placed below each pot to prevent leaching into the soil and cross contamination among pots. Basal dressing of nitrogen-phosphorus-potassium (N-P-K) at $30 \mathrm{kgha}^{-1}, 20 \mathrm{kgha}^{-1}$ and $30 \mathrm{kgha}^{-1}$ respectively was applied as urea, single superphosphate and muriate of potash respectively. The plant height, number of leaves, stem girth and leaf area were taken every 10-day intervals till final harvest at 30 days after transplanting when the above-ground biomass was clipped at soil level with stainless steel blade to separate the roots and then carefully rinsed in distilled water. Both the roots and above-ground biomass was oven dried in ventilated oven at $72^{\circ} \mathrm{C}$ for $48 \mathrm{hrs}$ to constant dry weight used in computing the nutrient uptake.

Field trial: The field trial was conducted in order to validate results obtained under greenhouse conditions. This field trial was sited where the soil for greenhouse trial was taken. The same heavy metal source as well as levels $(0,50,100,200 \mathrm{mg}$ per $5 \mathrm{~kg}$ soil) equivalent to 0,20 , $40,80 \mathrm{~kg} \mathrm{Pbha}^{-1}$ were used. Each treatment was represented by a bed size of $2.5 \mathrm{~m} \times 2.5 \mathrm{~m}$ separated by 50 $\mathrm{cm}$ space while each replicate was separated by $1 \mathrm{~m}$ alley. The entire experimental site was $12 \mathrm{~m} \times 10 \mathrm{~m}$ giving a total area of $120 \mathrm{~m}^{2}$ The various levels $\left(0,20,40,80 \mathrm{~kg} \mathrm{Pbha}^{-1}\right.$ ) of the heavy metal were uniformly applied with the aid of a spreader, mixed thoroughly and then left for 7 days before transplanting the seedlings. The experiment was organized in randomized complete block design in three replicates. The pumpkin was sown at a spacing of $1 \mathrm{~m} \mathrm{x}$ $1 \mathrm{~m}$. Each bed had a plant population of 4 plants. Hand weeding was done regularly. Similar rates of fertilizer were also applied in the field. The mode of data collection was similar to that of greenhouse trial.

Soil analysis: Soil samples were collected at the beginning and at the end of the trials to determine the following. The soil $\mathrm{pH}$ was determined at a soil to water ratio of 1:1 using a glass electrode $\mathrm{pH}$ meter. Particle size analysis was determined by the hydrometer method as modified by Day (1965).The organic carbon content of the soil was determined by using the chromic acid wet oxidation procedure as described by Jackson (1962). The nitrogen was determined by micro-kjeldal procedure as described by Jackson (1962) The protein contents were determined using the method of Azmat and Haider, (2007). Phosphorus was extracted by using Bray No. 1 P solution (Bray and Kurtz 1945) and the P in the extract assayed colorimetrically by the molybdenum blue colour method 


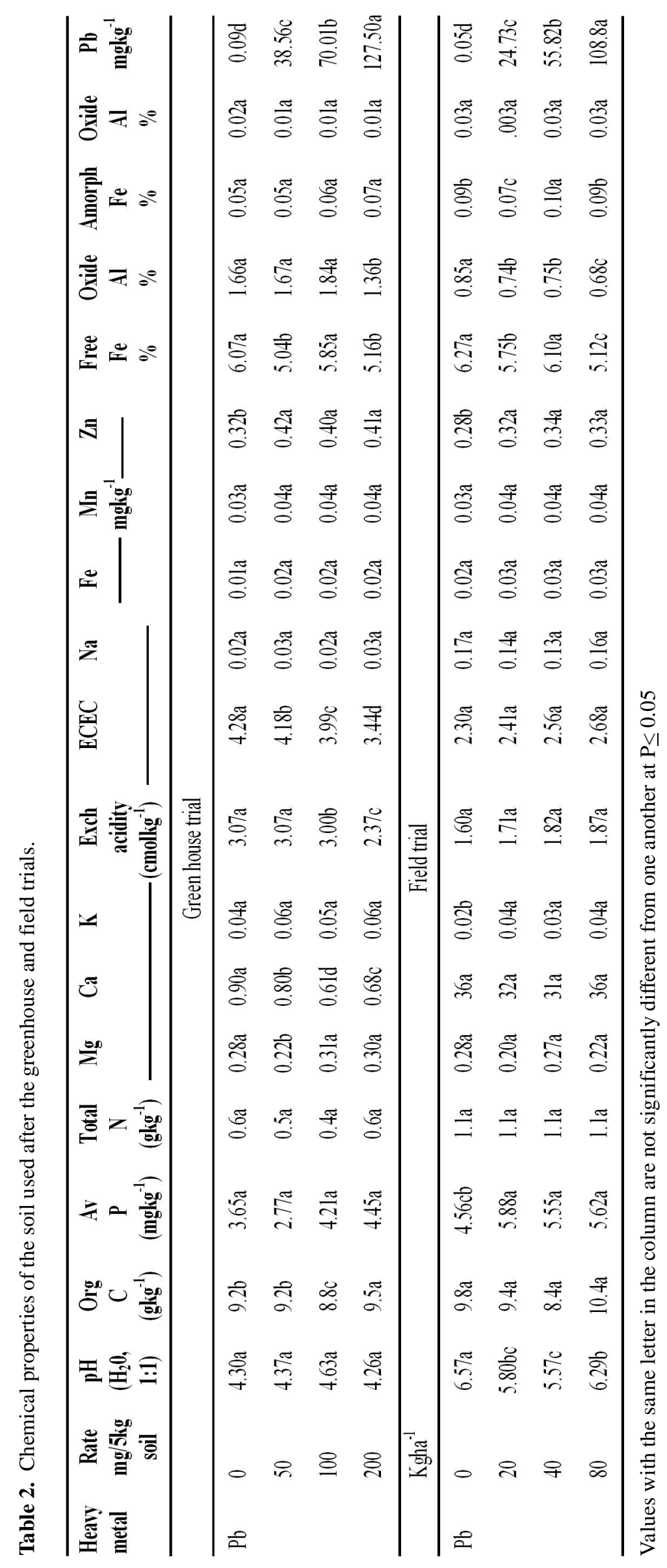




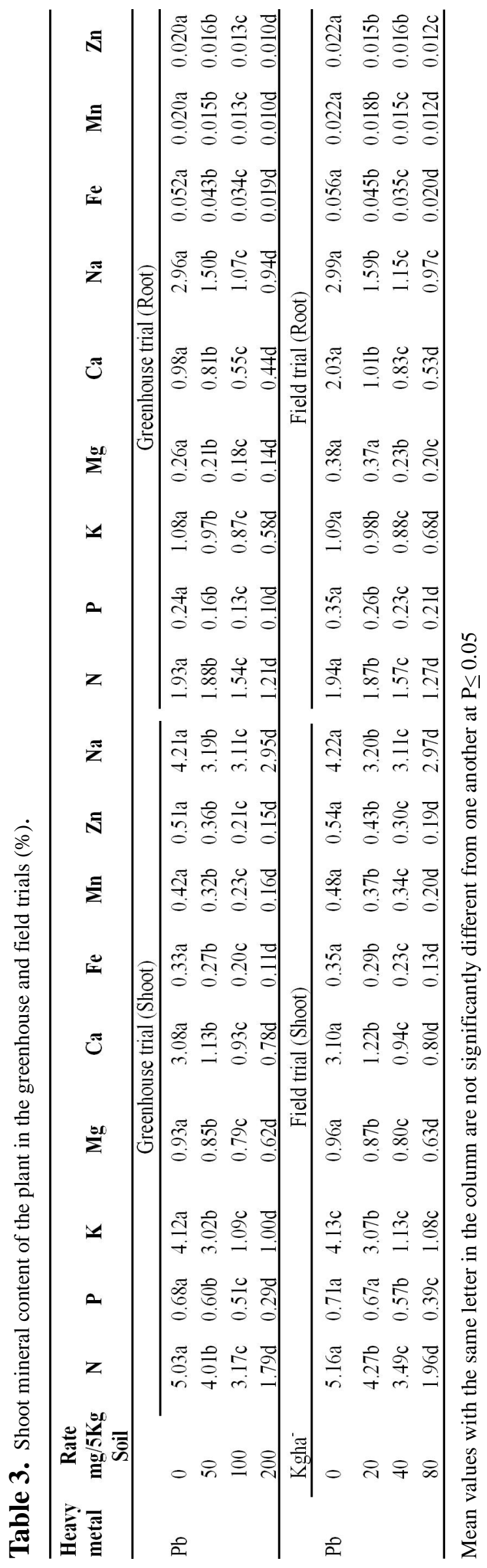

of Murphy and Riley (1962). The exchangeable bases were extracted using IN neutral ammonium acetate solution $\mathrm{Ca}$ and $\mathrm{Mg}$ content of the extract were determined volumetrically by the EDTA titration procedure (Black, 1965). The $\mathrm{K}$ and $\mathrm{Na}$ were determined by flame photometry and magnesium content obtained by difference. The exchangeable acidity was determined by KCl extraction and titration methods of Mclean (1965). The effective cation exchange capacity was calculated as the sum of exchangeable bases $(\mathrm{Ca}, \mathrm{Mg}, \mathrm{K}$ and $\mathrm{Na}$ ) and exchangeable acidity. The $\mathrm{Pb}$ and oxides were determined by methods of Soon and Abboud (1993). The data generated were analyzed by Genstat statistical version 6.1.0.234. (Payne, 2002).

Plant analysis: The plant materials were ground $(<1 \mathrm{~mm})$ and then digested with a mixture of $\mathrm{HNO}_{3}, \mathrm{H}_{2} \mathrm{SO}_{4}$ and $\mathrm{HCIO}_{4}$ acids (IITA, 1979). The mineral ions (Na, K, Ca, $\mathrm{Mg}, \mathrm{Fe}, \mathrm{Mn}, \mathrm{Zn}$ and $\mathrm{Pb}$ ) were determined by atomic absorption spectrophotometer (AAS UNICAM 969 ). For P content (A. O. A. C, 1970) perchloric acid digestion (wet oxidation) method was used while the micro-kjeldal method of Jackson (1962) was used for $\mathrm{N}$ determination.

\section{RESULTS}

Properties of the soil before the trials: The soil properties before the trials are shown in table 1.The soil $\mathrm{pH}$ is acidic and texturally sandy loam with percentage base saturation less than $35 \%$. The soil contains N, P, K, $\mathrm{Mg}, \mathrm{Ca}, \mathrm{Na}, \mathrm{Fe}, \mathrm{Mn}, \mathrm{Zn}$ and low $\mathrm{Pb}$ components.

Properties of the soil after the trials: Table 2 shows the properties of the soils used after the trials. The soil $\mathrm{pH}$ remain acidic while the organic carbon increased and decreased inconsistently in greenhouse and field trials respectively with no significant differences among the various treatments in organic carbon content of the soil. The available $\mathrm{P}$ also increased in at various levels of $\mathrm{Pb}$ treatment in the entire trials with significant differences recorded among the treatments in the field. The N, K, $\mathrm{Mg}, \mathrm{Ca}, \mathrm{Na}, \mathrm{Fe}, \mathrm{Mn}, \mathrm{Zn}$, exchangeable acidity, free $\mathrm{Fe}$ and $\mathrm{Al}$ oxides, amorphous $\mathrm{Fe}$ and $\mathrm{Al}$ oxides declined at various $\mathrm{Pb}$ treatments in the trials. There were however no significant differences in $\mathrm{N}$, exchangeable acidity, effective cation exchange capacity, $\mathrm{Na}, \mathrm{Fe}, \mathrm{Mn}$, amorphous $\mathrm{Al}$ oxide decrease. With the exception of $\mathrm{K}$ and amorphous $\mathrm{Fe}$ oxide in the greenhouse, significant differences were reported among the various $\mathrm{Pb}$ treatments in the field trial in $\mathrm{Mg}, \mathrm{Ca}, \mathrm{Zn}$, Free Fe oxide and Free $\mathrm{Al}$ oxide. The $\mathrm{Pb}$ content of the soil appreciated significantly with increased $\mathrm{Pb}$ application in the greenhouse and field trials.

Nutrient content and uptakeby the shoot and root of $\mathrm{T}$. occidentalis: The nutrient content of the shoot and root are shown in Table 3. The N, P, K, Mg, Ca, Na, Fe, Mn and $\mathrm{Zn}$ content of the shoot and root in the trials 


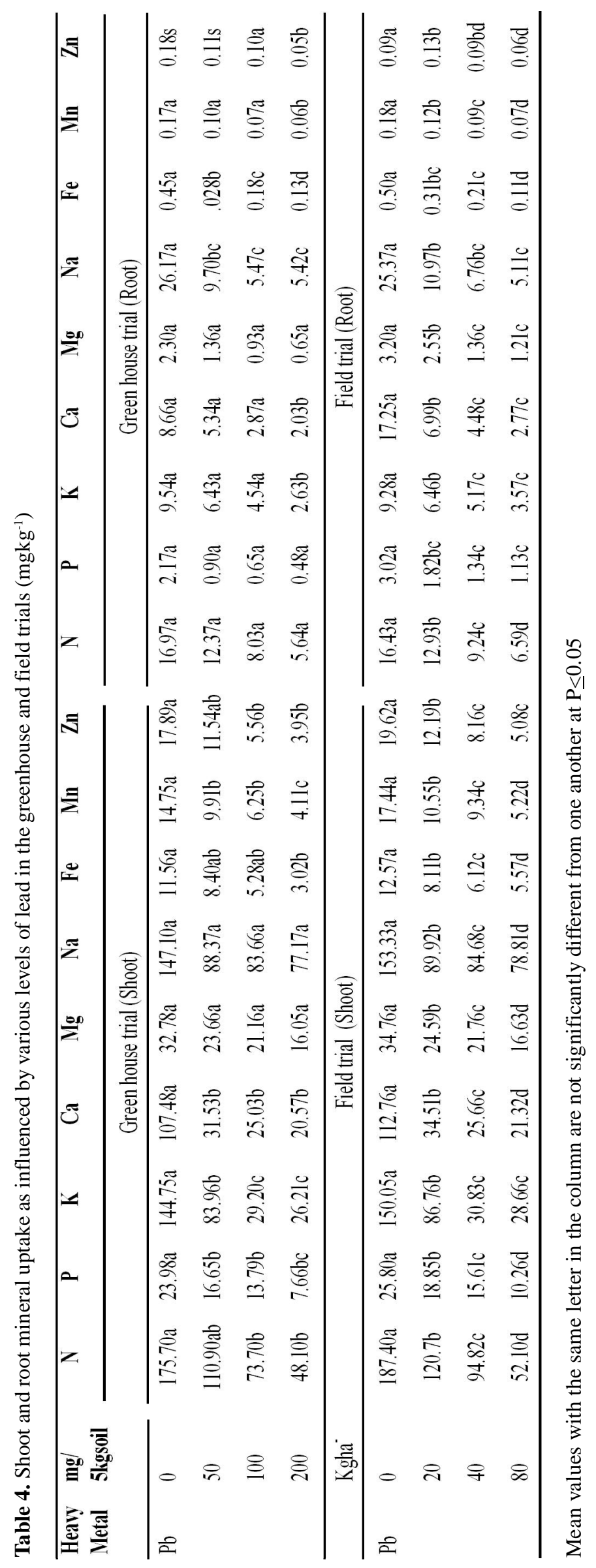


Table 5. Lead content $(\%)$ and uptake $\left(\mathrm{mgkg}^{-1}\right)$ by T. occidentalis in the greenhouse and field trials.

\begin{tabular}{|c|c|c|c|c|c|c|c|}
\hline \multirow[b]{2}{*}{$\begin{array}{l}\text { H eavy } \\
\text { metal }\end{array}$} & \multirow[b]{2}{*}{$\begin{array}{l}\text { Rate } \\
\mathrm{mg} / 5 \mathrm{~kg} \text { soil }\end{array}$} & \multicolumn{2}{|c|}{ Greenhouse trial } & \multirow[b]{2}{*}{$\begin{array}{l}\text { H eavy } \\
\text { metal }\end{array}$} & \multirow[b]{2}{*}{$\begin{array}{c}\text { Rate } \\
\mathrm{mg} / 5 \mathrm{~kg} \text { soil }\end{array}$} & \multicolumn{2}{|c|}{ Greenhouse trial } \\
\hline & & $\begin{array}{c}\text { Shoot } \mathrm{Pb} \\
\text { content }\end{array}$ & $\begin{array}{l}\text { Root } \mathrm{Pb} \\
\text { content }\end{array}$ & & & $\begin{array}{c}\text { Shoot Pb } \\
\text { uptake }\end{array}$ & $\begin{array}{l}\text { R oot Pb } \\
\text { uptake }\end{array}$ \\
\hline \multirow[t]{5}{*}{$\mathrm{Pb}$} & 0 & $0.08 \mathrm{~b}$ & $4.36 \mathrm{~b}$ & \multirow[t]{5}{*}{$\mathrm{Pb}$} & 0 & $2.74 b$ & $25.90 \mathrm{c}$ \\
\hline & 50 & $0.13 b$ & $6.01 \mathrm{~b}$ & & 50 & $3.52 \mathrm{~b}$ & $31.41 \mathrm{c}$ \\
\hline & 100 & $0.19 \mathrm{a}$ & $26.82 \mathrm{a}$ & & 100 & $5.20 \mathrm{a}$ & $93.58 \mathrm{~b}$ \\
\hline & 200 & $0.23 \mathrm{a}$ & $28.82 \mathrm{a}$ & & 200 & $6.22 \mathrm{a}$ & $128.76 \mathrm{a}$ \\
\hline & kgha $^{-1}$ & \multicolumn{2}{|c|}{ Field trial } & & kgha $^{-1}$ & \multicolumn{2}{|c|}{ Field trial } \\
\hline \multirow[t]{4}{*}{$\mathrm{Pb}$} & 0 & $0.004 \mathrm{~b}$ & $0.023 \mathrm{~d}$ & \multirow[t]{4}{*}{$\mathrm{Pb}$} & 0 & $0.13 \mathrm{c}$ & $0.20 \mathrm{~d}$ \\
\hline & 20 & $0.08 b$ & $2.50 \mathrm{c}$ & & 20 & $2.27 \mathrm{~b}$ & $16.99 \mathrm{c}$ \\
\hline & 40 & $0.19 \mathrm{a}$ & $5.87 \mathrm{~b}$ & & 40 & $5.22 \mathrm{a}$ & $34.76 \mathrm{~b}$ \\
\hline & 80 & $0.22 \mathrm{a}$ & $8.27 \mathrm{a}$ & & 80 & $5.87 \mathrm{a}$ & $43.71 \mathrm{a}$ \\
\hline
\end{tabular}

Mean values with the same letter in the column are not significantly different from one another at $\mathrm{P} \leq 0.05$

decreased significantly $(\mathrm{P}<0.05)$ with increased $\mathrm{Pb}$ application.

Table 4 shows the shoot and root nutrient uptake. The shoot and root nutrient uptake also decreased significantly $(\mathrm{P}<0.05)$ with increased $\mathrm{Pb}$ application in the trials.

$\mathrm{Pb}$ content and uptake by the shoot and root of $\mathrm{T}$. occidentalis: The $\mathrm{Pb}$ content and uptake by the shoot and root are shown in table 5 . The $\mathrm{Pb}$ content of the shoot and root increased significantly $(\mathrm{P}<0.05)$ with increased $\mathrm{Pb}$ application in the trials. The root however accumulated higher $\mathrm{Pb}$ than the shoot.

The uptake of $\mathrm{Pb}$ by the shoot and root (Table 5) increased significantly $(\mathrm{P}<0.05)$ with increased $\mathrm{Pb}$ treatment in the trials. Generally, the uptake of $\mathrm{Pb}$ by the root was higher than that of the shoot.
Crude protein content of T. occidentalis: The crude protein content of the plant (Table 6) decreased consistently with increased $\mathrm{Pb}$ treatments with the control treatments significantly higher than other treatments in the entire trials. The crude protein content of the shoot was higher than that of the root.

Dry matter yield of T. occidentalis: Table 7 shows the dry matter yield of the plant in the trials. The dry matter yield declined with the advancement in the application of $\mathrm{Pb}$. In the greenhouse trial there were no significant differences among various treatments in shoot and root dry matter while in the field significant differences were recorded in root and shoot dry matter.

Growth parameters of T. occidentalis: The growth parameters (Table 8 ) increased with the advancement of the plant growth stages and they were highest at harvest.

Table 6. Effect of lead on crude protein content of T. occidentalis in the greenhouse and field trials (\%).

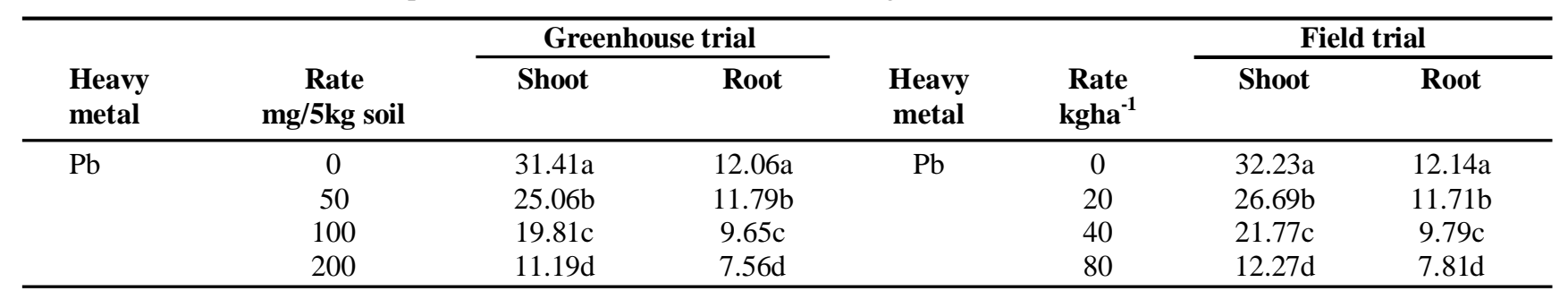

Mean values with the same letter in the column are not significantly different from one another at $\mathrm{P} \leq 0.05$

Table 7. Effect of lead on dry matter of T. occidentalis in the greenhouse and field trials (g).

\begin{tabular}{|c|c|c|c|c|c|c|c|}
\hline \multirow[b]{2}{*}{$\begin{array}{l}\text { H eavy } \\
\text { metal }\end{array}$} & \multirow[b]{2}{*}{$\begin{array}{c}\mathrm{mg} / 5 \mathrm{~kg} \\
\text { soil }\end{array}$} & \multicolumn{2}{|c|}{ Greenhouse trial } & \multirow[b]{2}{*}{$\begin{array}{l}\text { H eavy } \\
\text { metal }\end{array}$} & \multirow[b]{2}{*}{$\mathrm{Kgha}^{-1}$} & \multicolumn{2}{|c|}{ Field trial } \\
\hline & & $\begin{array}{l}\text { Root dry } \\
\text { weight }\end{array}$ & $\begin{array}{c}\text { Shoot dry } \\
\text { weight }\end{array}$ & & & $\begin{array}{c}\text { Root dry } \\
\text { weight }\end{array}$ & $\begin{array}{l}\text { Shoot dry } \\
\text { weight }\end{array}$ \\
\hline \multirow[t]{4}{*}{$\mathrm{Pb}$} & 0 & $0.88 \mathrm{a}$ & $3.50 \mathrm{a}$ & $\mathrm{Pb}$ & $\overline{0}$ & $0.85 \mathrm{a}$ & $3.63 a$ \\
\hline & 50 & $0.66 \mathrm{a}$ & $2.77 \mathrm{a}$ & & 20 & $0.69 b$ & $2.83 b$ \\
\hline & 100 & $0.51 \mathrm{a}$ & $2.69 \mathrm{a}$ & & 40 & $0.59 \mathrm{c}$ & $2.72 b$ \\
\hline & 200 & $0.47 \mathrm{a}$ & $2.61 \mathrm{a}$ & & 80 & $0.53 \mathrm{~d}$ & $2.65 c$ \\
\hline
\end{tabular}

Mean values with the same letter in the column are not significantly different from one another $(\mathrm{P} \leq 0.05)$ 
The plant height, number of leaves, stem girth and leaf area decreased significantly $(\mathrm{P}<0.05)$ with increased $\mathrm{Pb}$ application. Generally, the control treatments in the trials had higher values than other treatments at final harvest. Visual obser vations of T. occidentalis : It was observed that the leaves of the plant treated with $200 \mathrm{mg} \mathrm{Pb}$ and 80 $\mathrm{kg} \mathrm{Pbha}^{-1}$ developed anthocyanin pigmentation as from 20 days after transplanting in the greenhouse and field trials.

\section{DISCUSSION}

The properties of soil used indicated that the soil is low in fertility, which is typical of an ultisol as shown by its low percent base saturation (less than 35\%). The low percent base saturation that distinguished it from Alfisol (Brady and Weil, 2002). The particle size revealed that the soil is sandy loam and was not influenced by the applied heavy metal (No data). The decrease in some of the soil nutrient content such as $\mathrm{N}, \mathrm{P}, \mathrm{K}, \mathrm{Mg}, \mathrm{Ca}, \mathrm{Na}$ and organic carbon was not consistent. The fluctuation of these mineral nutrients may be tied to the plants uptake at different levels of $\backslash \mathrm{Pb}$ applied. The decrease in oxides may be due to their solubility as a result of low $\mathrm{pH}$ in the soil used. Generally, oxides solubility is very low at the $\mathrm{pH}$ range of soils and depends on the particle size, crystallinity and the percent of Al substitution (Schwertmann, 1991). The $\mathrm{pH}$ of soil used may have favoured the reduction in the oxides. The quantification of oxides in soils and sediments is often complicated by a considerable variation in crystallinity (Schwertmann et al, 1985) but it is estimated that iron oxides concentrations in various soils vary from $<0.1$ to $>50 \%$ and they may be evenly distributed in the matrix or concentrated in horizons concretion, mottles, bands or clay minerals coating (Schwertmann, 1991). The oxide values obtained in this study compared well with the estimated range of $<0.1 \%->50 \%$ as reported by Schwertmann above. The increase in the $\mathrm{Pb}$ content of the soil is attributed to the increase in the amount or concentration of the $\mathrm{Pb}$ applied to the soil. Similarly Gundermann and Huctchinson (1995), Tam and Singh (2004) also found elevated heavy metals in soil contaminated heavy metal mine spoils.

The decrease in growth parameters because of increase in the $\mathrm{Pb}$ treatments may be attributed to the influence of $\mathrm{Pb}$ especially in the higher dosage. Stunted growth recorded especially in those treated with the metal is a commonly observed growth response in a wide range of plants grown in metal-laden soils. This result further strengthens earlier report of Foy et al. (1978) that heavy metals decrease plant vegetative growth. The reduced shoot and root biomass of the $\mathrm{Pb}$ treated plants in this study can also be due to specific toxicity of the metal to the plant, antagonism with other nutrients in the plants or inhibition of root growth in the soil. Similar results have earlier been made by Azmat et al. (2006) in Phaseolus mungo and Lens culinaris. The presence of anthocyanin pigmentation in leaves of plants treated with higher $\mathrm{Pb}$ can be ascribed to a deficiency of phosphorus. The $\mathrm{Pb}$ reported earlier by Johnson and Proctor (1977), Johnson et al. (1977) have been known to form insoluble complexes with phosphorus leading to anthocyanin pigmentation (visual observation) in the leaves of plants. Similar anthocyanin pigmentation and inhibited growth have also been reported by Daniel-Davis (1996) as cited by Begonia (2006) in a corollary greenhouse study involving India mustard treated with $500 \mathrm{ug} / \mathrm{ml} \mathrm{Pb}$. The depression in root growth in the $\mathrm{Pb}$ treated soils could also be attributed to lack of oxygen because of $\mathrm{Pb}$ application. Godzik (1993) has also asserted it that nutrients are generally absorbed against concentration gradients; consequently respiratory energy is required for mineral uptake. In order for respiration to continue in the roots, oxygen must be available in root zone (Azmat and Haider, 2007). Roots, which become totally submerged in soil contaminated by heavy metals, will suffer from lack of oxygen and this will lead to slow growth and inhibitory effect of toxic metal on roots of plants (Jones et al., 1973). The Pb may have altered the levels of mineral elements in the roots by physically blocking off mineral ions from absorption sites of roots. The inhibition of root growth as demonstrated by the root weight after exposure to the $\mathrm{Pb}$ may be related with decrease in $\mathrm{Ca}$ in the root tips of Telfairia occidental is leading to decrease in cell division or cell elongation as earlier reported by Rout and Das (2003) with Norway spruce plants and Paude et al. (2007) with Brahmi plants.

Higher $\mathrm{Pb}$ concentration caused imbalances of micro and macronutrients in growing plants as shown or revealed in this study. This result supports the finding of Eun et al. (2002) who reported that high concentration of heavy metal in environment causes imbalance of minerals in growing plants. Many observed action of $\mathrm{Pb}$ appear to be indirect as a result of mineral imbalance within the tissue of Telfairia plants bringing significant changes in nutrients in plants under the heavy metal toxicity. Reduction in nutrient content as well as in internal ratios of nutrients may have occurred in the Telfairia plants under $\mathrm{Pb}$ stress as observed earlier by Pinero et al. (2002). The $\mathrm{Pb}$ may have damaged the tissue cells of vascular bundles, which resulted in the inhibition of conduction of water molecules from root to aerial parts of the plant hence there was reduction in plant nutrients, which led to slow growth and development. This reduction in plant nutrients is similar to the finding of Eun et al. (2002) and Azmat et al. (2006). The decrease in the uptake of nutrient by shoot and root may be attributed to interference of the metabolism of mineral nutrients by $\mathrm{Pb}$ application. Two mechanisms for decreased uptake of nutrients under 
heavy metal toxicity have been suggested. The first mechanism termed physical, relies on the size of metal ion radii, whereas second mechanism, which is a chemical one, relies on the metal-induced disorder in the cell metabolism leading to change in membrane enzymes activities and membrane structures (Azmat and Haider, 2007). These mechanisms may have occurred on Telfairia plant hence the decrease in plant nutrient uptake.

The protein content of both the shoot and root also decreased with increase application of the heavy metals. This result is similar to the finding of Okyto (1997) with $39.2 \%$ crude protein and Oboh (2005) who reported 38\% crude protein in Telfairia plants grown in soils not contaminated with heavy metals. The depression of the protein content is attributed to the decrease in uptake of some minerals by the plant. For instance, the $\mathrm{K}$ acts as a coenzymes or activator of many enzyme systems (KabataPendias and Pendia, 1992). Higher K levels according to Schreinemaker (1984) are needed for protein synthesis. In this study, the excess $\mathrm{Pb}$ applied may have caused leakage of $\mathrm{K}$ ions, which may have depressed protein formation in both shoot and root.

There was a significant difference between the aerial and root organs of the plant with respect to applied $\mathrm{Pb}$ and resultant accumulation trend of $\mathrm{Pb}$. In the result, more $\mathrm{Pb}$ was found higher in the root than the shoot making the plant Telfairia a metal excluder. A metal excluder plant according to Raskin et al. (1994) prevents metal from entering their aerial part or maintains low and constant metal concentration over a broad range of the concentration in soil and they mainly restrict metal in their root as demonstrated by Telfairia in this study. The ability of the metal excluder to restrict heavy metals to root is based on the mechanisms that actively growing roots provide a barrier, which restricts the movement of heavy metal to above ground parts of plants. This restricted movement by root in addition to low mobility of $\mathrm{Pb}$ may explain why heavy metal concentration in shoots was relatively less than in the root. Jones et al. (1973), Malone et al. (1974), Begonia (2006) have earlier reported similar results. This point in view was further substantiated by the earlier finding of Kumer et al. (1995), which showed that significant heavy metal translocation to the shoot of Indian mustard was only relatively high at high concentration of heavy metal in the hydroponics solution and after the lead-binding capacity of roots was partially saturated.

\section{Conclusion}

The study revealed that the presence of $\mathrm{Pb}$ had an effect on plant performance by altering the rate of nutrient uptake, synthesis and translocation of vital mineral elements in the plant. The soil nutrient elements were not enhanced by the application of $\mathrm{Pb}$ rather more $\mathrm{Pb}$ 
accumulated in the soil. The low concentration of this heavy metal in the shoot in control treatments at harvest is below specified maximum acceptable level of $0.3 \mathrm{mgkg}^{-1}$ for leafy vegetables by the WHO (1984) and Codex Alimentarius Commission (2004). The low level of this metal in control treatment makes the plant not to be hazardous to health when consumed. Those treated with $\mathrm{Pb}$ deviated from this acceptable level making it hazardous to health when regularly consumed. However, the decrease in crude protein content of the plant because of increase in $\mathrm{Pb}$ application could reduce the nutritive value of the plant and then heavy metal load in food and human nutrition. Conclusively, soils suspected to accumulate high levels of $\mathrm{Pb}$ should be avoided when cultivating fluted pumpkin.

\section{REFERENCES}

Association of Official Analytical Chemists (A.O.A.C) (1970). Official methods of analysis Ed 11 Washington D. C.

Azmat, R. and Haider, S. (2007). Pb Stress on phytochemistry of seedlings Phaseolus mungo and Lens culinaris. Asian J ournal of Plant Science, 6 (2): 332-337

Azmat, R., Haider, S. and Askari, S. (2006). Phytoxicity of $\mathrm{Pb} \mathrm{I}$ : Effects of $\mathrm{Pb}$ on germination, growth, morphology and histomorphology of Phaseolus mungo and Lens Culinaris. Pakistan J ournal of Biological Science, 9:979-984

Begonia, G.B. (2006). Comparative lead uptake and responses of plants grown in lead contaminated soils. www.ejoun3.htm.

Black, C.A. (1965). Methods of soil analysis.Agronomy No 9 Part 2. America Society of Agronomy Madison, Wisconsin.

Brady, N.C. and Weil, R.R. (2002). The nature and properties of soils. $13^{\text {th }}$ Edition. Hall Upper Saddle River, New Jersey.

Clark, R.S. (1995). Marine Pollution, $3^{\text {rd }}$ edition Oxford University Press London 169p

Codex Alimentarius Commission (2004). Report of the $36^{\text {th }}$ Session of Codex Alimentarius Committee on Food Additives and Contaminants Rotterdam, The Netherlands 22-26 March

Day, P.R. (1965). Particle fractionation and particle size analysis: In methods of soil analysis, (C.A. Black Ed).Agronomy No 9 Part 1. American Society of Agronomy Madison, Wisconsin

Eun, S.O., Youn, H.S. and Lee, Y. (2002). Lead disturbs microtubile organization in root meristem of Zea mays. Physiology of Plants, 110:357-365.

Forstner, U. (1995). Land contamination by metals: Global scope and magnitude of problem In H. E. Allen; C. P. Huang; G. W. Bailey and A. R Bowers eds. Metal speciation and contamination of soil CRC Press, Boca Raton FL 133pp.

Foy, C.D., Chaney, R.L. and White, M.C. (1978). The physiology of metal toxicity in plants. Annual Review of Plant Physiology, 29:511-566.

Geeblen, W. J., Vangronsveld, D. C., Adriano, L. C., Poucke and Clijsters, H. (2002). Effect of Pb-EDTA and EDTA on oxidative stress reactions and mineral uptake in Phsaeoulus vulgaris. Physiology of P lants. 115: 377-384

Godzik, B. (1993). Heavy metal contests in plants from zinc dumps and reference area. Poland B otanical Studies.5:113132.

Goldbold, D. L. and Kettner, C. (1991). Lead influence on root growth and mineral nutrition of Picea abies seedlings. Journal of Plant Physiology 139: 95-99

Gundermann, D.G. and Hutchinson, T.C. (1995). Changes in soil chemistry 20 years after the Closure of nickel-copper smelter near Sudbury, Ontario, Canada. Geochemical Exploration. 52.231 - 236

Haider, S., Kanwal, S., Uddin, F. and Azmat, R. (2006). Phytoxicity of Pb II: Changes in chlorophyll absorption spectrum due to toxic metal $\mathrm{Pb}$ stress on Phaseolus mungo and Lens culinaris. Pakistan J ournal of Biological Science, 9:2062-2068

Jackson, M.L.(1962). Soil chemical analysis. Prentice Hall, New York. 263-268

Johnson, M.S., McNeilly, T. and Putwain, P.O. (1977). Revegetation of metalliferous mine soil contaminated by lead and zinc. Environmental Pollution,12: 261-277.

Johnson, W.R. and Proctor, J. (1977). A comparative study of metal levels in plant from two contrasting lead mine sites. Plant and Soil, 46: 251-257.

Jones, L.H.P., Clement, C.R and Hoope, M.J.(1973). Lead uptake from solution by perennial ryegrass and its transport from root and shoots. Plant Soil, 38:403-414.

International Institute of Tropical Agriculture (IITA) (1979). Selected methods for soil and plant analysis. Manual Series No 1. PP 70

Kabata-Pendia, A. and Pendias, H. (1992). Trace elements in soils and plants. $2^{\text {nd }}$ Edition CRC Press Boca Raton, London.

Keresan, S., Petrovic, N., Popovic, M. and Kandrac, J. (2001). Nitrogen and protein metabolism in young pea plants as effected by different concentration of nickel, cadmium and molybdenum. Journal of Plant Nutrition 24 1633-1644

Khan, D. H. and Frankland, R. (1983). Effects of cadmium and lead on raddish with particular reference to movement of metals through soil profile and plant. Plant and Soil, 70: 335-345.

Kumer, P.B.A.N., Dushenkov, V., Matto, H. and Raskin, I. (1995). Phytoextraction the use of plants to remove heavy metals from soils. Environmental Science and Technology. 29:1232-1238

Malone, C.D., Koeppe, D.E. and Miller, R.I. (1974). Localization of lead accumulated by corn plants. Plant Physiology, 53:385-394.

Mclean, E.O. (1965). Aluminium. In: Methods of soil analysis(ed C.A Black) Agronomy No 9 Part 2. American Society of Agronomy, 978-998.

Moffat, A. S. (1995). Plants growing their worth in toxic metal clean up. Science 269: 302-303.

Murphy, J and Riley, J.P. (1962). Analytical chemistry. Acta, 27:31-36.

Oboh, G. (2005). Nutritional and safety evaluation of some tropical green leafy vegetables. J ournal of F ood Technology, 3 (3): 389-392.

Okyto, B.N. (1997). Neglected plants of horticultural and medicinal importance in traditional farming system in Tropical Africa. Acta H orticulture, 131-149.

Paude, P, Chand, S. Vinod, K. Anwa, M. and Patra, D.D. (2007). Influence of Chromium with Vermicompost on 
growth and accumulation by Brahim. Communication in Soil Science and Plant A nalysis, 38. 2815-2829.

Payne, R.W (2002). Gent stat 6.1: Reevence manual VSN International Ltd. Oxford.

Pinero, H.J.L, Miti, R.K., Julia-Verdestar, M.A, Diaz G.G, Dnzalez, A.N., Cardenas Avila, M.L. and Orough-Bakhih, R. (2002). Effect of $\mathrm{Pb}$ and $\mathrm{Cd}$ on seedlings, growth, chlorophyll and protein contest of common bean (Phascolus vulgaris), alfa alfa (M edigago sativa), avena (Avena santiva and rye grass (Lolum multiflorum) selected as hyper accumulator of heavy metal. Research on Crops, 3:473480.

Raskin, I., Kumar, P.B.A., Dushenkovs, N. and Salt, D. (1994). Bio-concentration of heavy metals by plants. Current O pinion on Biotechnology. 5: 285-290.

Rout, G.R. and Das, P. (2003). Effect of metal toxicity on plant growth and metabolism I Zinc. Agronomic, 23:3-11.

Schreinemakers, W.A. (1984). Effect of metal ions on growth and on ion absorption by spir odela polyrbaza (L) Schleiden.
Effects of iron, magnesium and zinc Z. Pflanzen Physiology. 114:123-129.

Schwatmann, U, Philippe, C. and Murad, E. (1985). Properties of goethite varying in crystalinity clays and clay minerals. 33:369-378.

Schwertmann, U. (1991). Solubility and dissolution of iron oxides. Plant and Soil, 130:1-25

Soon, Y.K. and Abboud, S. (1993). Cadmium, chromium, lead and nickel In: Soil sampling and methods of soil analysis (eds M.R. Carter). Canadian Society of Soil Science. 101108

Tam, Y. L. and Singh, B. (2004). Heavy metals availability at industrially contaminated soils in NSW, Australia: In A.L. Juhaz, G. Magesan and R. Naidu (eds). Waste Management, Science. Publishers Plymouth 97- 120

WHO (World Health Organization) (1984). Guidelines for soil, water and plant quality. Vol. 1 Recommendation W.H.O. Geneva 130p. 